\title{
A Study on the Coping Strategy of Financial Supervisory Organization under Information Asymmetry: Case Study of Taiwan's Credit Card Market
}

\author{
Chih Hsiung Chang ${ }^{1}$, Heidi H. Chang, ${ }^{2, *}$, Jui-Chu Tien ${ }^{1}$ \\ ${ }^{1}$ Department of Finance, College of Management, I-Shou University, Kaohsiung, Taiwan \\ ${ }^{2}$ Department of Entertainment Management, International College, I-Shou University, Kaohsiung, Taiwan
}

Copyright $\bigcirc 2017$ by authors, all rights reserved. Authors agree that this article remains permanently open access under the terms of the Creative Commons Attribution License 4.0 International License

\begin{abstract}
Information asymmetry has been a commonly existed phenomenon in banking system. This paper adopted consumer finance data from both government-owned and private- owned banks in Taiwan, variables such as numbers of effective cards, percentages of overdue loans, and revolving interest rate are used to investigate if information asymmetry phenomenon existed in Taiwan's credit card market. During the research period, Taiwan had suffered from severe crisis of credit card debt, financial supervisory organization interfered into the credit card market passively, hoping to improve the information asymmetry phenomenon of the credit card market. However, the research results show that not only information asymmetry phenomenon has not disappeared from Taiwan's credit card market, but worsen the adverse selection phenomenon and promoted moral hazard in certain degree.
\end{abstract}

Keywords Credit Card, Information Asymmetry, Moral Hazard, Adverse Selection

\section{Introduction}

Credit card is one type of consumer finance tools that can complete the payment and transaction without cash and it is simple credit loan provided by the financial organization. In addition to basic function of general consumption-before-payment, the card holders do not need to pay completely the consumed value of the present month. Instead, the card holder can use a way similar with loaning which is a revolving credit way for flexible payment. The credit card can further be expanded to a function of pre-borrowing the cash. In the beginning of 1990s in Taiwan, under the great promotion of the Ministry of Finance and National Credit Card Center, the credit card business in the bank started to have great advancement.
Until December 2014, credit card in circulation domestically (total number of card issued minus total number of card stopped, and the card situation is normal) has reached 37.4 billion cards. Meanwhile, the signature-payment value of that year even reached 194.5 billion New Taiwanese dollars (NTD), as compared to 400 thousand cards and 12.5 billion NTD of signature-payment value at the end of the year of 1989, the explosive increase of number of card issued and signature-payment value unbelievable.

At the end of 2005, card debts crisis was exploded in Taiwan, 700 thousand people have become card-slaves, and the average money owed was one million NTD. The card issuing bank was accused of non-controlling issuance of card just for receiving high interests, which had led to the result that the card holders cannot pay the debt due to excessive consumption and finally become card slave doomed eternally. In December the same year, the Legislative Bureau had tried to propose an act to reduce the revolving credit interest rate of the bank from the upper limit of $20 \%$ to $10 \%$. Financial Supervisory Commission and bank association, coping with this crisis, had to propose "debt negotiation mechanism" platform, while differential interest rate has to be implemented, and the original "three five eight" policy had to be adjusted. Three-five-eight policy is to prevent banks from over issue the credit cards. Although multiple actions had been implemented at the same time to reduce the total number of credit card issued and the debt value, the card debt crisis still had a large negative influence on Taiwan's economy.

Since debt negotiation mechanism was only self-disciplined convention among banks and it did not have any forced power like the law. Therefore, facing with severe card debt crisis, its effect was quite limited. Taiwan Legislative Bureau, further on June of 2007, had passed Statute for Consumer Debt Clearance to clarify that for card debt people of non-secured or non-priority right debt with 
value below 120 million NTD, they can pay the debt through negotiation, reproduction and liquidation. Meanwhile, even bankruptcy mechanism for natural person was acquired at that moment so that the card credit people can have a short chance to breathe.

In February 2015, even through legislation, the interest rate of cash card or the revolving interest rate of credit card in the bank was forced to be lower than annual interest rate of $15 \%$. Such action to the card-issuing bank with large revolving credit balance and with revolving interest rate for card holder mostly falling on the maximal upper limit of $20 \%$, did have the impact from policy obviously more severe than the past.

Since 1989 when visa cards were introduced to Taiwan, it had opened a new face in the credit card development history of Taiwan. During business development period of Taiwan's credit card market, due the lack of business experience of the card-issuing bank and the rough business model of pure pursuit of card issuance number, or maybe as well as the purposed manual operation on the market through the use of information asymmetry phenomenon existed in the financial market, an unprecedented card debt crisis was exploded in 2006. All these showed that the original role function of capital mediating and the reduction of information asymmetry phenomenon needed to be exploited by the card-issuing bank in the financial bank was no longer in existence already. Therefore, being the supervisory organization for the monitoring and management of financial market, the Financial Supervisory Commission had to make aggressive intervention into the market so that the information asymmetry phenomenon in domestic credit card market can be reduced, and eventually, the derived credit card debt crisis can be solved. However, although the supervisory organization had to make aggressive intervention into the market, what was the effect? It has become the target to be investigated in this paper.

\subsection{Information Asymmetry}

The information asymmetry meant that different parties participating in the transaction had different capabilities to own information that might affect the transaction. General speaking, the seller usually might have more information regarding the product in transaction than the buyer. However, the opposite situation might exist. In fact, information asymmetry phenomenon generally existed in finance, insurance, automobile, labor, or even internet auction market [1] -[5], therefore, this paper focused on whether the credit card market of domestic finance market existed information asymmetry phenomenon, and the derived adverse selection and moral hazard.

The 2001 Nobel laureate in Nobel economics prize, George Akerlof, had a famous lemon car theory, which applied the information asymmetry theory in the used car market [6], and it was found that car of the same year and the same model will have different quality performance due to difference in the car driving habit and maintenance level of the previous car owner. However, except the owner himself, the buyer was not clear about the real quality of each car, therefore, information asymmetry was formed. If there was a market price on that model of used car, it can only reflect its "average quality", however, if the used car owner felt that the condition of his own car was superior to the average quality, he will not be willing to sell it in a price that only "reflected the average quality". Therefore, when the used car of good quality was forced to withdraw from the market, it made best explanation to the market failure resulted from information asymmetry.

Hruba [7] had used the foods market in Czech as example to point out that not only credence information was difficult to be acquired in Czech, but also familiarity bias existed in Czech's food market, therefore, research result regarding factors affecting consumer's behavior and decision making attitude cannot be drawn to a conclusion. From this, it was clear that information asymmetry had huge influence.

Hoshik [8] had used emerging markets as example to explain, due to information asymmetry, the disclosure effect of a company usually was difficult to be expected, because before the disclosure, information leakage existed everywhere already. However, even though, the research results showed that even if you stayed at information poverty and information leakage environment, negative association still existed between fair disclosure activity and information asymmetry, on the contrary, it was positive association. Shiri [9] claimed more directly that the ownership structure and disclosure quality of capital market in Iran were all affected by information asymmetry phenomenon. All these had highlighted important role played by information asymmetry on affecting fair disclosure standard of the companies in the newly emerging markets.

\subsection{Adverse Selection}

Ausubel [10] had noticed the adverse selection issue in the credit card market, and it meant that commercial bank, under the same condition, was more willing to loan the capital to an individual with more property and higher income, however, these people, starting from optimization of their own effectiveness, might not want to apply for credit card by borrowing the money to consume. On the contrary, individual with lower income and less property, in order to enhance his own effectiveness level, might more likely apply for credit card actively to perform overdraft consumption. When these overdraft consumptions cannot be collected back smoothly or even form bad debt, in addition to violating strongly the accreditation principle of pursuing safety in the commercial bank, such result also explained the adverse selection phenomenon derived from information asymmetry in credit card market.

Liao [11] had used the survey data of consumer finance in 15 cities in Mainland China to investigate the adverse 
selection issue in domestic credit card market. Under the condition of controlling other variables, the relationship between the credit line and income fluctuation of the card holder was studied, and the result showed that card holder with higher income fluctuation tends to gain higher credit line, which had verified the adverse selection conclusion existed in credit card market.

Lai and Huang [12] had investigated the credit card business in the Liu-Nan Branch of Agricultural Bank of China, and it was found that adverse selection was a commonly existed phenomenon in the credit card market, which reflected that there was indeed an adverse selection mechanism in the market, and such mechanism had made customers with "strong ability of paying back and low risk" get credit condition inferior to customers with "weak ability of paying back and high risk". Therefore, high attention was paid to the hazard brought about by adverse selection, and prior review and management was totally enhanced for credit card business, consequently, the reduction of information asymmetry not only has its meaning of fulfillment, but in the meantime, it also provided a preventive and solution thinking for the development of credit card business in other commercial banks.

Of course, adverse selection not only existed in credit card market, take the national health insurance market as example, since the tax policy of US was regressive to the health insurance, plus the deduction way taken in the subsidy, instead, an adverse selection phenomenon of a person with higher income can get higher subsidy was formed [13]. Yu [14] has also mentioned the issuance of professional journal, when editor was searching for appropriate reviewers, adverse selection phenomenon usually was derived due to agent problem.

More specifically, adverse selection might even affect the higher education of a country. Del [15] pointed out in the research that when higher education was seen as high risk investment, and student was risky averse person, if high education fee cannot be arranged appropriately, for example, through deferring payment, or all students were forced to participate in public funds that had insurance characteristic, adverse selection phenomenon will exist and impact seriously higher education of a country.

Time Magazine [16] pointed out directly that the decision of sustainability and acquirers' performances of a joint venture should not just focus on benefit-cost analysis, the potential threat coming from adverse selection issue should not be neglected at all. All these had highlighted a phenomenon that adverse selection indeed existed in every corner, and it continuously had influence and impact on many industries.

\subsection{Moral Hazard}

The moral hazard of credit card meant that after an individual had applied for a credit card, due to information asymmetry between the card-issuing bank and the card holder, card-issuing bank usually cannot have effective monitoring on the card holder. Therefore, the card holder might have certain behavior that might hurt the benefit of the card-issuing bank, for example, malicious overdraft without considering his own income status, or even refuse to pay back the debt, which might bring a bad debt to the bank, that is, in credit card market, due to the adverse selection in the card-issuing banks, it might lead to moral hazard between the card-issuing bank and the card holder [ex. 17-19] .

Kao [20] pointed out that moral hazard meant that after the commercial bank had made a loan, due to information asymmetry between the commercial bank and the enterprise, commercial bank usually cannot make effective monitoring on the enterprise, which might lead to the enterprise to make behavior that might harm the benefit of the bank. For example, when the commercial bank loaned the capital to the enterprise, it usually hoped that the enterprise can put great efforts to its business operation to get better profit. However, due to the existence of information asymmetry between the enterprise and commercial bank, after the acquisition of capital by the enterprise, the enterprise not only cannot apply the capital according to the direction expected by the loaning bank, but also make adverse high-risk investment, which eventually led to investment loss and incapability of paying back the debt. This is another example of moral hazard caused by information asymmetry [21].

Sun [22] mentioned, from the view point of information economics, moral hazard originated from the existence of information asymmetry, specifically speaking, in the operation of commercial bank, when one side of economic main body had information, and another side did not own the information or just owned part of the information. Therefore, when one side with more information, for the pursuit of its own profit optimization, it might bring damage and loss to the side with information inferiority, it was then called moral hazard.

Yeh [23] pointed out directly that credit card risk meant that the card holder did not follow the agreement signed with the card-issuing bank to pay back, within the agreed pay-back limit according to the regulation, the credit card consumed principal and interest, and the surcharge for overdue payment generated from it, which led to the loss of the card-issuing bank, and this was the so-called the moral hazard brought about by information asymmetry in the credit card market. In fact, since moral hazard will undermine the economy efficiency, economists have already seen it as issues that should be removed as soon as possible [24].

Rutger [25] even promoted financial crisis from financial problem to ethnic problem. Taking the global financial crisis in 2008 as an example, moral hazard originated from serious imbalance between banks and taxpayers in the financial market, the main reason was when the market was in good times, greedy banks, in order to get exorbitant profit, had made excessive risk-taking. Nevertheless, when the 
market is in bad times, the market loss derived from such risk has to be taken by the taxpayers. Traditional economic thinking had tried to de-moralize on such moral hazard and claimed that the moral hazard problem between the bank and the tax payers was nothing but normal economic agreement. Since then, criticisms on it never stopped.

Cornelius [26] pointed out directly that strategy to solve moral hazard and to pursue cost containment was the focus and core whether the insurance mechanism of a country can be maintained stably and continuously. It was clear that solving of moral hazard problems had become important and urgent problems that many countries had to face [27].

\section{Materials and Methods}

The research process is divided into five stages, and the first stage was to use credit card data provided by FSH of Finance Supervisory Commission to search if information asymmetry phenomenon existed in the credit card market. The second stage was, through literature review, to define clearly information asymmetry, adverse selection and moral hazard. The third stage was, under the theoretical basis of literature reading, to summarize, arrange and make statistical analysis on the acquired data. The fourth stage was to divide the financial organizations into publicly owned and privately owned banks so as to create diagrams and tables from the data such as effective card number, overdue loan percent, revolving interest rate to facilitate future empirical analysis. In the fifth stage, conclusion was proposed based on the empirical analysis result.

Literature reading method was used as the basic source of its theory, meanwhile, past data in the bank statistical database of Finance Supervisory Commission were used to conduct statistical analysis and summarization, meanwhile, credit card related data of privately owned banks and publicly owned bank of different years were compared, and quality analysis was conducted to summarize if both of them were affected by information asymmetry and adverse selection and moral hazard were derived.

Although this paper was of quality analysis, yet EXCEL statistical tool was applied to summarize related statistical data such as effective card number, maximal revolving interest rate and overdue loan percent, meanwhile, corresponding statistical diagram and table were accompanied to conduct empirical analysis of adverse selection and moral hazard. It was hoped that the research results of this paper can be more convincing and of more practical use, and it was even hoped that this paper can be used as important reference and source for the policy made by the supervisory organization.

\section{Results}

\subsection{Adverse Selection}

From the statistical data of table 1 , it can be seen that the highest revolving interest rate of publicly owned bank was usually much lower that of privately owned bank, however, the effective card number of privately owned bank was much higher than that of publicly owned bank, and such reverse selection phenomenon that obviously violates the market demand principle can explain that it at least existed the private-owned banks of credit card market in Taiwan. After further analysis (table 2), although the publicly owned bank had lower maximal revolving interest rate, yet its market share of effective card number was less than $2 \%$. Among all the financial organizations, Taiwan bank, which always had the lowest revolving interest rate, had market share even lower than $0.01 \%$. On the contrary, privately owned banks with maximal revolving interest rate fixed at the legally allowed maximal point $20 \%$, for example, Cathay United Bank, Citibank, E. Sun Bank and CTBC Bank, had market share of total effective card number as high as above $98 \%$ in recent decade. Adverse selection phenomenon and its possibly derived moral hazard problems, in Taiwan's credit card market, especially the private-owned banks, were seriously. Therefore, the subsequent empirical analysis result on moral hazard showed its importance.

Table 1. Effective card number and maximal revolving interest rate of credit card in 2005 and 2014

\begin{tabular}{|c|c|c|c|c|}
\hline & \multicolumn{2}{|c|}{2005} & \multicolumn{2}{c|}{2014} \\
\hline & Effective card number & $\begin{array}{c}\text { Revolving } \\
\text { interest rate }\end{array}$ & $\begin{array}{c}\text { Effective } \\
\text { card number }\end{array}$ & $\begin{array}{c}\text { Revolving } \\
\text { interest rate }\end{array}$ \\
\hline Bank of Taiwan & 178,354 & $10.80 \%$ & 116,586 & $11.78 \%$ \\
\hline Land Bank of Taiwan & 91,404 & $17.99 \%$ & 54,848 & $17.99 \%$ \\
\hline Cathay United Bank & $2,066,706$ & $19.70 \%$ & $3,366,147$ & $19.70 \%$ \\
\hline Citibank & $1,297,476$ & $20 \%$ & $2,490,900$ & $19.97 \%$ \\
\hline E. Sun Bank & $1,688,769$ & $19.71 \%$ & $2,540,538$ & $19.71 \%$ \\
\hline CTBC Bank & $4,235,270$ & $20 \%$ & $3,734,067$ & $20 \%$ \\
\hline
\end{tabular}

Data source: Finance Supervisory Commission 
Table 2. Annual effective card number of publicly owned and privately owned bank and market share of credit card number of privately owned bank in the recent decade

\begin{tabular}{|c|c|c|c|}
\hline & Publicly owned bank & Privately owned bank & Market share of privately owned bank (\%) \\
\hline 2004 & 445,226 & $24,143,378$ & $98.19 \%$ \\
\hline 2005 & 491,874 & $24,085,669$ & $98.00 \%$ \\
\hline 2006 & 401,764 & $20,004,589$ & $98.03 \%$ \\
\hline 2007 & 373,386 & $19,391,592$ & $98.11 \%$ \\
\hline 2008 & 362,058 & $19,093,184$ & $98.14 \%$ \\
\hline 2009 & 360,062 & $18,467,604$ & $98.09 \%$ \\
\hline 2010 & 379,197 & $19,148,533$ & $98.06 \%$ \\
\hline 2011 & 375,081 & $20,384,480$ & $98.19 \%$ \\
\hline 2012 & 393,981 & $21,103,935$ & $98.17 \%$ \\
\hline 2013 & 393,683 & $22,170,740$ & $98.26 \%$ \\
\hline 2014 & 410,189 & $23,955,766$ & $98.32 \%$ \\
\hline
\end{tabular}

Data source: Finance Supervisory Commission

From the statistical data of table 1, it can be seen that the highest revolving interest rate of publicly owned bank was usually much lower that of privately owned bank, however, the effective card number of privately owned bank was much higher than that of publicly owned bank, and such reverse selection phenomenon that obviously violates the market demand principle can explain that it at least existed the private-owned banks of credit card market in Taiwan. After further analysis (table 2), although the publicly owned bank had lower maximal revolving interest rate, yet its market share of effective card number was less than $2 \%$, among them, Taiwan bank, which always had the lowest revolving interest rate, had market share even lower than $0.01 \%$. On the contrary, privately owned banks with maximal revolving interest rate fixed at the legally allowed maximal point $20 \%$, for example, Cathay United Bank, Citibank, E. Sun Bank and CTBC Bank, had market share of total effective card number as high as above $98 \%$ in recent decade. Adverse selection phenomenon and its possibly derived moral hazard problems, in Taiwan's credit card market, especially the privately owned banks, were seriously. Therefore, the subsequent empirical analysis result on moral hazard showed its importance.

\subsection{Moral Hazard}

From figure 1, it can be seen that, starting from June of 2006, overdue loan percent of domestic credit card showed a descending trend in overall, which showed that moral hazard phenomenon existed in domestic credit card market in a long term basis was initially improved at this point. After further analysis (figure 2), it was found that before 2011, privately owned banks with occupation of the majority of effective card number in domestic credit card market, their overdue loan percent were still higher than that of publicly owned banks, which showed that moral hazard problems still existed domestic privately-owned banks. Until after 2011, along with rapid decrease of overdue loan percent in privately owned banks, or even lower than that of publicly owned bank, the moral hazard phenomenon in Taiwan's credit card market was eventually greatly improved.

In recent years, information propagation was easier and faster, and the scale of card-issuing organization became larger and larger, therefore, the card-issuing organization has great program in inspecting the debt-paying capability of the borrower, consequently, the situation of moral hazard was slowed down in the private-owned banks [28]. In addition to that, card debt crisis exploded in 2005 had brought lots of criticisms, therefore, it forced the finance supervisory organization to interfere into the market, from the birth of debt negotiation mechanism platform, to the pass of Statue for Consumer Debt Clearance through legislation, or even the great reduction of maximal revolving interest rate through the amendment of law, which showed the strong and problem-solving ambition of the supervisory organization when it had to face card debt crisis generated from information asymmetry. 


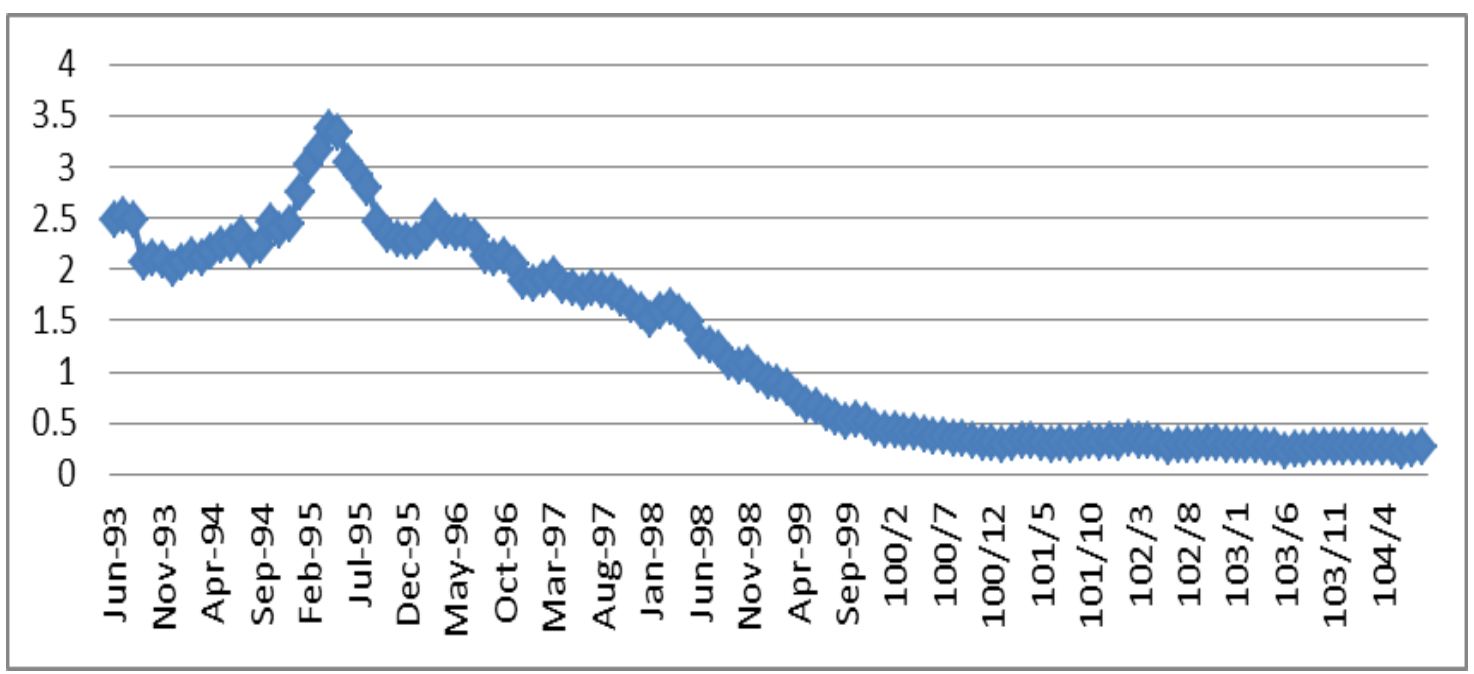

Figure 1. The overall overdue loan percent in recent decade. Data source: Finance Supervisory Commission

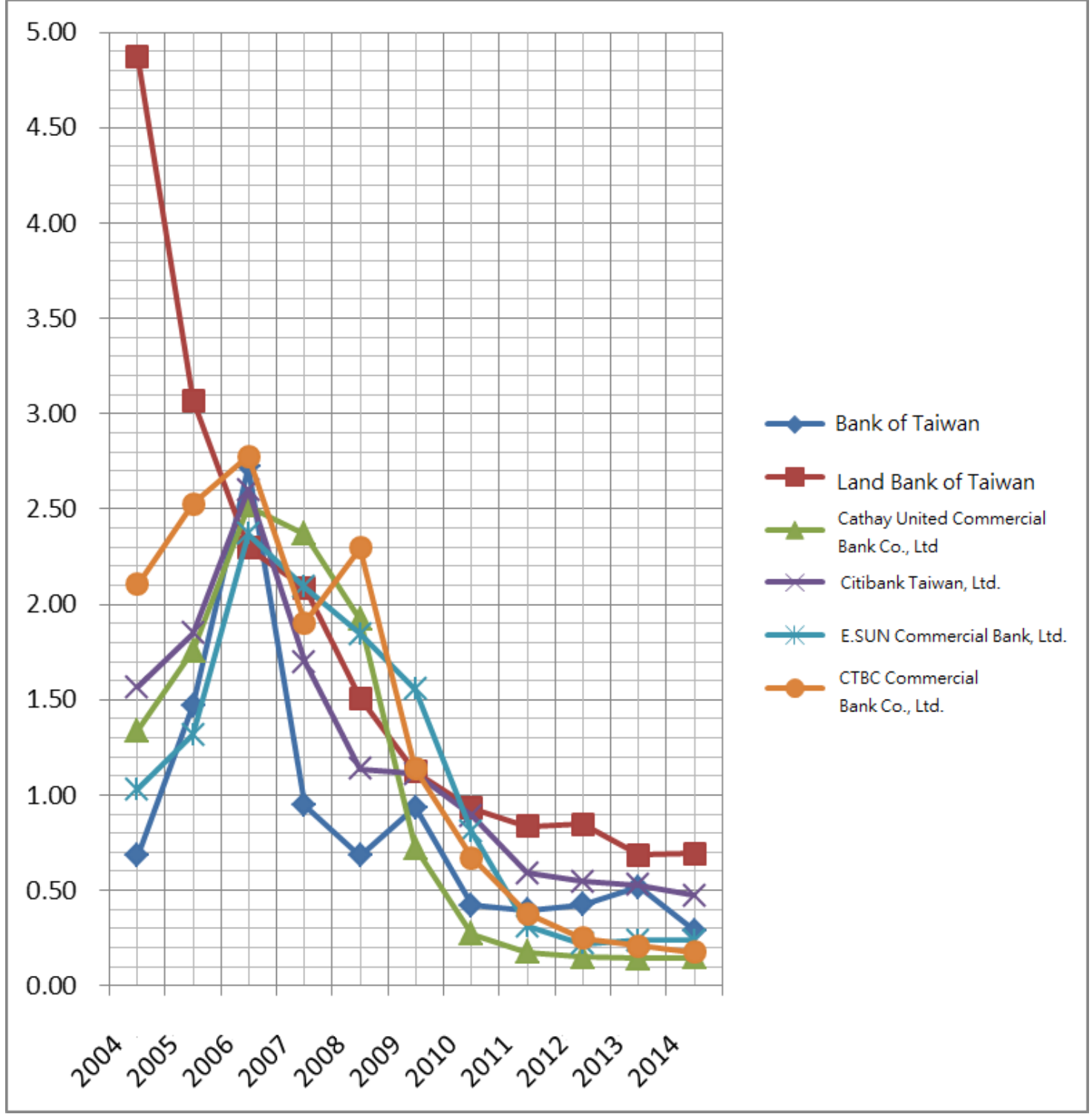

Figure 2. Overdue loan percent of credit card in each bank. (Data source: Finance Supervisory Commission). 


\section{Discussion \& Conclusion}

The father of economics Adam Smith once claimed that the operation of market depends on an invisible hand instead of the visible government policy, however, the premise was that the market should be in an ideal state o sufficient information and perfect competition [29]. However, perfect competition market was always just an idea because information asymmetry phenomenon did exist in the market, at this moment, it not only represented that an invisible hand, the market price mechanism, cannot operate normally, it will event lead to the serious results of market failure and the drop of social welfare. Facing with a failed market, the government or supervisory organization obviously should not confine itself to the free operation of the market price itself, on the contrary, it should come up with more aggressive action, although it might bring criticism for the government, however, this was a good time to show government's responsibility and determination [30].

The empirical result showed that Taiwan's credit card market was not an exception of the financial market, not only the existence of information asymmetry phenomenon, adverse selection and moral hazard even derived more serious social problem of card debt crisis, and it seemed that finance supervisory organization did not exist in Taiwan's financial market. Facing with severe criticism from the society, supervisory organization was finally forced to play a role of aggressive management on the financial market, from the birth of debt negotiation mechanism platform, to the pass of Statute for Consumer Debt Clearance through legislation, or even the great reduction of maximal revolving interest rate through law amendment, until 2011, information asymmetry phenomenon of Taiwan's credit card market was eventually greatly improved.

Obviously, the performance is a blemish in an otherwise perfect thing, because, as long as supervisory organization did not misunderstand its mandatory role in the management of financial market, or even losses a good chance in several times, a card debt crisis caused by information asymmetry, which was originally avoidable, will not have to take more than 10 years to get initial improvement. During this period, card debt crisis had changed its face from financial crisis into an overall social problem, and such a high price might beyond the capability of the supervisory to take. Lessons learned from the past can guide one in the future, the supervisory organization should think about it.

\section{REFERENCES}

[1] D. Marinescu. Dealing with Adverse Selection on Financial Markets, Economic Computation \&Economic Cybernetics Studies \&Research, 49(1):p72-84, 2015.

[2] P. Bajari. Moral Hazard, Adverse Selection, and Health
Expenditures: A Semiparametric Analysis, Rand Journal of Economics, 45(4):p747-763, 2014.

[3] G. Dionne, "Separating Moral Hazard from Adverse Selection and Evidence from France", Journal of the European Economic Association, 11(4):p897-917, 2013.

[4] J. Landeta, "Initiatives for the Improvement of Continuous Management Training", Cuadermos developing Gestion, 15(1):p61-91, 2015.

[5] D. Liu, Information Asymmetry and Hybrid Advertising, Journal of Marketing Research, 51(5):p609-624, 2014.

[6] Rosser. Jr.,. "A Nobel Prize for Asymmetric Information :the Economic Contributions of Grorge Akerl, Michael Sprnce and Joseph Stiglitz", Review of Political Economy, 15(1):p3-19, 2003

[7] R. Hruba, Behavior of Agents at Food Market, Especially Asymmetric Information on the Dairy Market, Journal of Applied Economics \&Business Research, 6(1):p36-54, 2016.

[8] S. Hoshik. "The Effectiveness of Regulation Fair Disclosure: Evidence from an Emerging Market", Emerging Market Finance \&Trade, 2015, 52(6):p1496-1511.

[9] M. Shiri. A Study of Impact of Ownership Structure and Disclosure Quality on Information Asymmetry in Iran",The Journal for Decision Makers, 41(1):p51-60, 2016.

[10] Ausubel. W. Lawrence. The Failure of Competition in the Credit Card Market, American Economic Review, 81(1):p50-82, 1991.

[11] H. Liao, A study on Taiwan's credit card development history and its social meaning change, Graduate Institute of Industrial Technology Education of National Kaohsiung Normal University, 2007.

[12] Y. Lai, L. Huang, Reverse selection in credit card business of commercial bank: An evidence from Liu-Nan Branch of Agricultural Bank of China, Journal of GuangXi University of Technology, 2012.

[13] K. Jeske, "U. S. Tax Policy and Health insurance Demand: Can a Regressive Policy Improve Welfare", Working Paper Series (Federal Reserve Bank of Atlanta),13:p1-46, 2007.

[14] H. Yu, Domestic bank loaning contract model to prevent the occurrence of adverse selection: A situation before the opening and setup of new bank, Management Review, 12, 83 $-98,1993$.

[15] R. Del. Deferring Higher Education Fees without Relying on Contributions from Non-students", Education Economics, 20(5): p510-521, 2012.

[16] Finance Supervisory Commission, Explanation of the decrease of upper limit of the interest rate of credit card and cash card based on bank act, news manuscript, 2015.

[17] S. Chen, X. Xi, "Reverse selection and moral hazard and credit rationing in loaning behavior", Jiangxi Social Sciences, $136-138,2005$

[18] C. Ge, Moral hazard model of credit loan market under information asymmetry, Guidebook for Decision Making, 38 39, 2006.

[19] C. Huang (2011), A study of the management effectiveness of 
financial organization under information asymmetry: take card debt of credit card as example, master thesis of master program of the department of finance of I-Shou University.

[20] A. Kao , Decisive factors of overdue loan percent of credit card in the bank: take Taiwan's banks as example, master thesis of graduate institute of finance of National Chengchi University, 2006.

[21] F. Xu, Prevention of information asymmetry and bank's credit loan risk, 5 (16), 2006 Sci-Tech Information Development \& Economy, 90 - 91, Management School of Anhui University

[22] Z. Sun, "A study of the control mechanism of moral hazard of domestic commercial banks", session 1 of 2006 Northern Economy and Trade, P87 - 89, School of Finance, Harbin University of Commerce.

[23] S. Yeh, "A study of management effectiveness of financial organization under information asymmetry theory: take the card debt of cash card as example", master thesis of master program of the department of finance of I-Shou University, Taiwan, R.O.C, 2012.

[24] N. Tumennasan, Moral Hazard and Stability, Social Choice \&Welfare, 43(3):p659-682, 2014.
[25] C. Rutger, Financial Crisis and the Ethics of Moral Hazard, Social Theory \&Practice, 41(3):p527-55, 2015.

[26] D. Cornelius, An Explanation of Moral Hazard Behaviors under the National Health Insurance Scheme in Northern Ghana: a Qualitative Study, BMC Health Services Research, 15:p1-9, 2015.

[27] H. Yim. The Ex post JV Sustainability and Acquirers' Performances under the Potential Threat of Adverse Selection Problem Economic Computation \& Economic Cybernetics Studies \& Research, 49 (2):p237-255, 2015.

[28] T. Feng, Analysis of information asymmetry and game theory of asset theory of commercial bank, session 2 of 2007 Economic Research Guide, P65 - 67, Economics School of Anhui University, 2007.

[29] G. Zhao, A study on the credit risk management of credit card business of commercial bank, Ph.D. dissertation of East China Normal University, 2007.

[30] H. Liao, A study on Taiwan's credit card development history and its social meaning change, Graduate Institute of Industrial Technology Education of National Kaohsiung Normal University, 2007. 